\title{
Macroeconomics Relations between Exchange Rate Instability, Exchange Rate Volatility, Trade and Economic Growth Variables: The Case of Pakistan
}

\author{
Muhammad Zubair ${ }^{1}$, Prof. Dr. Anwer Irshad Burney ${ }^{2}$, Salman Sarwat ${ }^{3}$, Muhammad Mubin ${ }^{4}$ \\ 1.MBA, Federal Urdu University of Arts, Science Technology, AH Campus, Karachi \\ 2.Associate Professor in Economics, Govt. National College, Karachi \\ 3.Assistant Professor in Commerce, Benazir Bhutto Shaheed University, Lyari, Karachi \\ 4.Lecturer in Commerce, Govt. Degree Science and Commerce College, Lyari, Karachi \\ *Corresponding Author: Email: mubinamin@hotmail.com
}

\begin{abstract}
This paper aims to determine whether Exchange Rate instability of Pakistan, affects it's imports, Exports, Trade Balances, Foreign Exchange Reserves and GDP of Pakistan or not, and if so then in what direction. We have used pooled data from 1952 to 2010 (on annual basis), indirect exchange rate quotations (Dollars per Rupee) are used. We have estimated our equation by running each variable at lag 3, Estimated equation of explanatory variables (Exchange Rate, imports, Exports, Foreign Reserves) for explained variable (GDP) exhibits a significant relationship, which is highly sensitive. A change 1 basis point in exchange rate can result in thousand of USD change in GDP. The depreciation of exchange rate has a positive impact on the exports, but sudden and abrupt fluctuation in exchange rates can disturb economic growth. We have used: Correlation Removal methods, Multi-collinerity Detection and Removal Tests, Stability Test, Granger Causality Test, Auto correlation Detection and Removal Tests, in-order to make our model and it's variable, a "good predictor" for determining the Trade Balances of Pakistan, significant enough, for future predictions about GDP.
\end{abstract}

Keywords: Exchange rate instability-Volatility, Trade, Imports, Exports, Economic Growth, Reserves Money, Auto-Correlation Detection \& Removal Test, Stability Test, Granger Causality Test, Multi-Collinerity.

\section{INTRODUCTION}

Exchange rate is an important macroeconomic variable and a vital factor in international trade. "Exchange rate" is the price of one currency in terms of another currency. The variability in exchange rate plays an important role in the determination of trade balance. Volatile exchange rate slows down the process of trade, destabilizes the capital movements, and shatters the confidence of investors, which slows down the process of growth. Volatility refers that how exchange rate is settled on demand and supply of domestic currency vis-à-vis to foreign currency. Exchange rate volatility can influence policy decisions, affect the volume of exports, imports and reserve money, and disturbs the allocation of productive resources and balance of payments. Exchange rate volatility provides chances to domestic investors to invest in foreign currency to obtain higher profits and thus domestic currency depreciates and economy's growth becomes venerable. The objective of the study is to see impact and the relationship of exchange rate instability on trade and GDP of Pakistan. Empirically, "Appreciation" of the exchange rate affects exports negatively and imports positively, conversely, "Depreciation" has reverse effects.

Exports of Pakistan are mainly based on manufacturing and agriculture sectors with less value addition. Instability on Real exchange rate plays a vital role in determining the competitiveness of trade, real depreciation makes the home products cheaper in the world market, which Increases the level of Exports of a country. So, devaluation helps in improving the trade balance and association would be negative. However, some researchers argues that exchange rate does not significantly affect the Exports or imports of the country unless the exchange rate is highly changed i.e. "Highly Undervalued or Highly Overvalued" and no other incentives are given to the traders, Since the Exchange Rates of Pakistan, changes rapidly, therefore, it is expected that, in-stability in Exchange Rate, will considerably affects the Trade Balance of Pakistan.

Import of capital goods plays an important role in enhancing the exports, these imports could be in the form of raw materials, machineries or both, those are used in the manufacturing sector. But, trickling effect of import of capital goods on export may take two period lags on average as setup and production process may take considerable time. Abrupt changes in exchange rate is expected to have a significant negative impact on the imports of the Pakistan, because in a small developing country the importers play safe and cautious role than any other developed country because of less risk taking and resources limitations. Similarly, growth instability will also have significant impact on imports. FOREX reserves are the vital element in determining the volume of import as a country with limited FOREX reserve has to rely on foreign borrowings or she might cut down imports. Therefore it is expected to have positive association between FOREX reserves and imports. Trade Balance Deterioration leads to exchange rate depreciation, therefore it is expected to have positive association between - Devaluation of the currency and the trade balance. Analogous to it, there is a positive association 
between FOREX reserves and Devaluation of exchange rate. However, in the era of free trade and globalization, tariff and non-trade barriers might also play an important role in trade and consequently on exchange rate. will yield positive coefficient of real devaluation.

Many researchers explains the exchange rate 'as a random walk process', they argued that the exchange rate can only be explained by its lagged value [Meese and Rogoff (1987)]. Excess appreciation of exchange rate will yield negative coefficient of real devaluation whereas excess deprecation

\subsection{Purpose of the Research:}

The aim of my study is to find the relationships between exchange rate instability, trade (imports \& exports), reserve money and economic growth (GDP Variables). Our Hypothesis is that whether Exchange Rates affect Trade, Reserve Money and GDP, or Trade, Reserve Money and GDP affects the Exchange Rates.

\section{HISTORY OF MODEL'S VARIABLES, WITH REFERENCE TO PAKISTAN:}

\subsection{Exchange Rates:}

Pakistan's Exchange Rates was maintained for nearly 35 year through a fixed peg regime. Due to the member of the Sterling area, the first link of Pakistani rupee was developed with the Great Britain's pound. The rupee was depreciated and Devalued in June 1955, for the very first time by $30 \%$. This devaluation of Pak rupee in relation to pound sterling was made, in order to make it be brought in line with the currencies of other trading partners of our Country. The, Pakistan's Nominal exchange rate for about the next seventeen years period was remained fixed at Rs. $4.76 / 1$ US dollar. The second change occurred in 1972, exchange rate depreciated by $58 \%$, then in 1973, Rupee was further devalued by $10 \%$. This new rate remained as an official exchange rate between these two countries till Jan 1982

On the recommendation of IMF, flexible exchange rates by the government changed the system of pegging rupee. Under this system, exchange rate of Pakistani rupee is determined by the State Bank of Pakistan on behalf of government of Pakistan. The exchange rate under this system is determined on the basis of weighted average of Pakistan currency with currencies of its major partners in trade. The exchange rate market which was under strict control in 1980s became relatively open under the system of managed float in 1990s. Supply and demand of currencies became the base for the determination of an Exchange rate in the market. Thus, the difference between official exchange rate and kerb rate is very nominal. The value of rupee was depreciated by about $230 \%$ during the 9 years, started from 1982 to Jun 1996. From 1993 onwards, depreciations or technical adjustments by the SBP were supplemented by direct devaluations.

History of exchange rate of Pakistan shows a continuous trend of deprecation each year but in 2002/3, the rupee has been appreciated in the value against with that the US dollar bucking the earlier trend. The reason for this was the event of 9/11. Stability in Exchange Rates has been observed since then till 2007. In the year 2008-09 PKR was depreciated by $20 \%$ and revolved around this level till 2011.

\subsection{GDP Growth Rate in Pakistan:}

Since 1947, the average annual economic growth rate of the Pakistan remained at $5.3 \%$. But due to high growth rate of population of our country, growth rate of per capital GNP was remained at level of 2.3 percent per annum. Gross National Product's growth rate in our country has declined rapidly, during the periods 1970 to 1977 , but after that, it remained around 7 percent per annum on average. This growth rate continued until the fiscal year of 1985-1986. During this period, both political stability and economic stability were complementary each other. The decade of the 1990s was somewhat economically stagnant, and then an era of accelerated economic growth was started with beginning of new millennium. Pakistan had become one of the four fastest growing economies in the Asia. The Zardari-Gilani government inherited a relatively sound economy on March 31, 2008. It inherited foreign exchange reserves of \$13.3 billion, exchange rate at Rs62.76 / US dollar, the KSE index at 15,125 with market capitalization at $\$ 74$ billion

\subsection{Trade Openness in Pakistan:}

Trade openness of Pakistan's economy has been a gradual process. Although, Pakistan's economy was not so closed one but it was not so opened also. Economical growths of a country can be improved by increasing its export to the others countries. Exports demand of any country depends upon the several factors, like prices, product quality, and economic conditions of importing country. Traditional view favors depreciation (of currency) due to its ability to decrease exporting goods prices which increases competitiveness in international market, thus increases the production of goods, which can be traded in the domestic and foreign market. But empirically, it has also been noticed that devaluation frequently decreases the output of any country and ultimately becomes the source of recession. Imports, although may have a negative effect on foreign exchange reserves of the country, may add to well being of people of a country but it can also affect the domestic output adversely. Import and export of Pakistan in 1975 were 53.185 billion Rupees and it reached to the level of 212.019 billion Rupees by 1985 . This figure increased to 619.882 billion Rupees in 1995 and 2,130.061 billion Rupees at the end of 2005 . 


\section{REVIEW OF LITERATURE:}

The worldwide adoption of floating rates regime attracted much of economic discussion and attention. Theory recommends that exchange rate volatility; exports, imports, manufacturing products, and reserve money in the presence of Keynesian Open Economies (perfect capital mobility) have deep relationship with each others. Theoretically, if depreciation of Pakistan's currency exists, this will increase competitiveness of domestic goods and hence encourage exports, on other hand depreciation is expected to reduce Imports and improve trade balance. De Grauwe (1988) suggested that the relation between exchange rate volatility and trade should be positive if the model is correctly and accurately specified. But empirical investigations showed that there is no consensus about it because of existence of mixed pattern of results found in the studies.

Mahmood (2011) investigated the impact of volatility of exchange rate on macro-economic performance of the Pakistan by using annual data from 1975 to 2005 . He Augmented Dickey Fuller (ADF) test and OLS test on variables. The results indicated that GDP and manufacturing products of Pakistan are positively affected by volatility of exchange rate, while its negative effect has been found on real exports and foreign exchange reserves of Pakistan. Zakaria and Ghauri (2011) presented Trade openness of Pakistan and real exchange rate; by using quarterly data from 1972 to 2010, they revealed a significant positive effect of trade openness on the real exchange Rate of Pakistan. The results are based on the alternative trade openness measure and different model specifications. Their results also highlighted the role of other variables like Government consumptions, FDI, capital inflows and the capital accumulations in the determination of the real exchange rates.

Suleiman D. Mohammad \& Adnan Hussain (2009), studied the role of exchange rate on balance of trade of Pakistan. Their study examines validity of the Marshall Lerner condition in Pakistan by using data annually from 1970-2008 and applying J- curve idea and Johansson Co Integration Test. They found long run relationship among the variables at Vector 2. Zahoor Hussain Javed \& Muhammad Farooq (2009) investigated the relationship of economic growth \& exchange rate volatility in Pakistan. They examined the impact of exchange rate volatility on macroeconomic variables like imports (M), exports (X), manufacturing products (MP) and reserve money (RM). They used Augmented Dicky-Fuller (ADF) and Philips Perron (PP) unit test to find the order of integration of macroeconomic variables, using quarterly data from 1982 -1 to 2007-IV.

Nusrate Aziz (2008) applied the Engle \& Johansen techniques to investigate the long run co-integration relation between Trade Balance and Reer, and employed the ECM to explored the short run linkages. Results indicated that reer has an impact on Bangladesh's Trade balance on both short and long run. Shaista Alam (2006) investigated the impact of exchange rate volatility on Pakistan's aggregate exports demands (to the rest of the world) by employing quarterly data for the period 1979 Q3-2005 Q4. Their empirical results based on the ARDL analysis show that real exports are co integrated with foreign economic activity, real effective exchange rate and volatility of real effective exchange rate. Aasim M. Husain (2006) assessed whether or not the characteristics of Pakistan's Economy makes it an appropriate candidate for a pegged exchange rate regime. He found a small effect of the exchange rate variability on trade and investment,

Zulfiqar Hyder and Adil Mahboob (2006) studies equilibrium real effective exchange rate and exchange rate Misalignment in Pakistan, They used the annual data from 1978 to 2005, Engle Granger co-integration technique was used to estimate the EREER based on various macroeconomic fundamentals that had been suggested in economic literature by Edwards, Elbadawi and Montiel . The results indicate that the variables which determine the EREER, depreciates the REER, while, other variables such as the increase in workers' remittances and the improvement in terms of trade and total factor productivity relative to trading partners appreciated the REER. The results are suitable in Long Runs. Marjan Petreski (2006) found the reverse relationship between the choice of Exchange Rate Regime and the Macro-variables.

Ortega \& Giovanni (2005) suggested empirically the impact of trade cost on volatility of real exchange rate. M. Kemel (2005) used simultaneous equation model using three stages least square technique, and found that instability of exchange rates significantly affects exports positively and imports negatively. Khan and Sajid (2005) with reference to Pakistan investigated relationship between real money balances, real income, inflation rate, foreign interest rate $\&$ real effective exchange rate for both the long as well as the short run, over the period of 1982:Q2 to 2002:Q4. Their results indicating that in the long run real income, inflation rate foreign interest rate and real effective exchange rate have a significant impact on the real money balance in Pakistan.

Helmut Herwartz and Henning Weber (2004) analyzed the impact of FX uncertainty on sectoral categories of multilateral exports and imports for 15 industrialized economies of the world, providing a comparison of linear and nonlinear models with respect to ex-ante forecasting. De vita and Abbott (2004) investigates the impact of exchange rate volatility on UK exports to European Union (EU) countries by means of a newly developed ARDL bounds testing procedure to co integration. Using monthly data from1993 to 2001, their results indicated that UK exports to the EU14, at both aggregate and sectorial level, are generally income elastic, relative price inelastic and largely unaffected by short-term exchange rate volatility. Re-estimation of the model using a longterm measure of volatility, however, provides evidence supporting the hypothesis that exchange rate uncertainty has a negative and significant influence on UK exports to EU countries. 
Mustafa and Nishat (2004) examined the impact exchange rate volatility on exports growth between Pakistan and various regions; and concluded that the relationship between exports growth and exchange rate volatility for India and Pakistan found in long run only. Abott et. al (2001), Doyle (2003), and Arize (1995, 1996, 1997, 1998) proposed that in the long as well as in the short run a significant relationship exists between exchange rate instability and imports \& exports. Kumar and Dhawan (1991), Cushman (1983), Akhtar and Hilton (1984), Pozo (1992), Persson \& Svensson (1989) have found that influence of exchange rate uncertainty has adverse affect on imports \& exports. Progoff (1998) stated that a significant problem would be created for both importers and exporters by flexibility of exchange rates. Gognon (1993) and Bayomi (1996). Cooper (1999) compared the scope of different exchange rate choices availed by rich and developing countries. Zhang (2002) review China's foreign exchange reforms and analyzed and reviewed their impact on the balance of trade and inflation. Aurangzaib et al. (2005) investigated the Relationship among economic performance, growth and exchange rate uncertainty in Pakistan. Qayyum \& Kemal (2006) found that there is a strong relationship exit between the volatility of foreign market and volatility of stock markets return.

\section{DATA AND METHADOLOGY}

\subsection{Data}

Our study consists of time series pooled data from 1952 to 2010. Multiple Electronic Data sources including World Bank data-Base \& SBP, \& Pacific Exchange Forex. These are the quantitative analysis using deductivepositivism approach. Since the data for GDP from1952 to 1960 were not available in US Dollars, therefore, we have converted GDP data in PKR to USD by using exchange rates- prevailed at that time. For accuracy, data in thousands of Dollars are used. Indirect quotations of exchange rates with reference to Pakistan are used.

\subsection{Explanation of the Variables}

\subsubsection{Exchange Rates}

Foreign exchange rates (the price of one country's currency in terms of another) are important because they affect the price of domestically produced goods sold abroad and the cost of foreign goods bought domestically. The theory of purchasing power parity suggests that long-run changes in the exchange rate between two countries are determined by change in the relative price levels of the two countries. Other factors that affect exchange rates in the long run are tariffs and quotas, import demands, export demand, and productivity. In the short run, exchange rates are determined by the interest parity condition, which states the expected return on domestic deposits is equal to the expected return on foreign deposits. The exchange rates volatility is also determined by Asset Market approach. Forecasts of foreign exchange rates are very valuable to the importers, exporters, financial institutions and Government.

After World War II, the Bretton Woods system and the IMF were established to promote a fixed exchange rate system in which the U.S dollar was convertible into gold. The Bretton Woods system collapsed in 1971. We now have an international financial system that has elements of a managed float and a fixed exchange rate system. Available evidence suggests that sterilized central bank interventions have little long-term effect on the exchange rate. Controls on capital outflows receive support because they might prevent domestic residents and foreigners from pulling capital out of a country during a crisis and make devaluation less likely.

\subsubsection{Imports}

Purchasing goods or services from one country by another country in a legitimate fashion is called import. Import of goods normally requires involvement of the customs authorities of both the country, and is often subject to import quotas, tariffs \& trade agreements. The term "imports" as macroeconomic variable refers to the economic value of all goods and services that are imported over a given period of time, usually one year.

\subsubsection{Exports}

Selling goods or services by one country to another country in a legitimate fashion is called export. Like import, export is also subject to quotas, tariffs and trade agreements; and it represents economic value of all goods and services that are sold across borders in one year. Exports, along with imports, form the basis of international trade.

\subsubsection{Reserves (Foreign Money)}

Foreign-exchange reserves (forex reserves) refer to the foreign currency deposits and financial instruments held by central banks and other monetary authorities. However, the term in popular usage also includes various foreign currencies, gold and Special Drawing Rights - SDRs (IMF fiat currency). This broader figure is more readily available. Forex reserves are the assets of the central bank, and used to back its liabilities.

\subsubsection{Gross Domestic Product}

Gross domestic product (GDP) refers to the market value of all final goods and services produced within a country in a given period. This is the most important macroeconomic indicator showing the productivity or level of economic activity of a country.

\subsection{Model}

To prove the reliability of our samples we first estimate our equation as follows:- 


$$
G D P(-3)=\beta 0+\beta 1 E R(-3)+\beta 2 M(-3)+\beta 3 X(-3)+\beta 4 R M(-3)+\mu
$$

Where,

$\begin{array}{lll}\mathrm{GDP} & = & \text { Gross Domestic Product } \\ \mathrm{ER} & = & \text { Exchange Rates (Dollars / Rupee) } \\ \mathrm{M} & = & \text { Total Imports of Goods and Services } \\ \mathrm{X} & = & \text { Total Exports of Goods and Services } \\ \mathrm{RM} & = & \text { Reserve Money (including Gold Reserves) } \\ \mu & = & \text { Error Terms of the Model }\end{array}$

Where, $\beta 0$ is coefficient of dependent variable, and $\beta 1, \beta 2, \beta 3, \beta 4$ are the coefficient of independent variables.

This is a Multiple Regression Model with 5 Parameters, including 4 slopes and 1 intercept. Error term should be small, otherwise our model is not properly explained by the variables. $\beta 0$ is a constant, indicating that what would be the value of Dependent Variable (Here GDP) if all the Values of Explanatory Variables becomes Zero. If the Results of our model are significant, so we can say that Variables are True Estimates, otherwise False Estimates, if insignificant.

Our Null hypothesis is $\mathrm{H}_{0}$ : $\quad \mathrm{B} 1=0, \quad \mathrm{~B} 2=0, \mathrm{~B} 3=0, \quad \mathrm{~B} 4=0$

Our Alternative hypothesis is $\mathrm{H}_{\mathrm{A}}: \quad \mathrm{B} 1 \neq 0, \quad \mathrm{~B} 2 \neq 0, \quad \mathrm{~B} 3 \neq 0, \quad \mathrm{~B} 4 \neq 0$

Reject Ho when values of coefficient are significant i.e. relationship exists between dependent and independent variable(s), otherwise we can reject null hypothesis in favor of $\mathrm{H}_{\mathrm{A}}$. Type 1 and Type 2 error will exits, if variables is/are insignificant, so it means there is Multi-collinerity.

If $r^{2}=0.99$, the model is explaining $99 \%$ of the variables, However if $r^{2}>0.7$ and if most of the variables are insignificant, so there is Multi-collinerity existing in the data, which needs to be removed. There should be the relationship between dependent and independent variables only, but there should not be the relationship between independent variables.

If there are less than 40 observations, parameters in the regression equation are said to be insignificant, also when we apply lags in out equation, so by applying lags, the number of observations decreases, e.g. at lag 1, no of observations is 39 and 38 with lag 2 and so on. After applying Tests of Multi-collinerity Removals, Even, if we are finding any variable as insignificant, so as a lender of Last Resort, remove that particular variable, i.e. its relationship with dependent variable does not exist; we can also observe that $r^{2}$ remains almost same, by removing such a variable. By estimating correlation in software packages such as E-VIEWS etc., we can determine correlation between variables; Matrices of independent variables can be created, which shows relations among independent variables.

Their interpretation is that the correlation values of 0.5 or 0.6 is said to be normal, However 0.7 value means high correlation is existing, so if higher correlation exists in value of a variable(s), then there is Multi-collinerity in that variable(s), and Estimator(s) are neither true nor reliable. This is the Multi-collinerity Detection Method. We have removed Multi-collinerity by the applying lag method.

\subsubsection{Results}

The Results of our Model has been elaborated, under the Following Section:

\section{Estimation of the Econometric Model}

The Estimated Econometric model is as follows: $G D P(-3)=6183072-17853988 E R(-3)+1.236149 M(-3)+4.053665 X(-3)+0.818944 R M(-3)+\mu$

According to the Estimated Values of our Equation, if one unit of $M$ (imports) increases (due to change in Exchange Rate), so GDP is affected by 1.236 Units, Whereas, if one unit of X (Exports) increases, so GDP is affected by 4.05 Units, and if one unit of RM (Reserves) increases, so GDP is affected by 0.819 Units, Although, Imports sign is against the theoretical model, that Imports leads to increase in GDP, However, this is an indication that, Pakistan is a country, whose Total imports is mostly based on the Imports of Capital Goods (such as Machinery, Plants, \& Raw Materials etc., which can be used to produce further Goods, and ultimately increases the GDP), rather than the imports of Consumer goods as Major Imports (Goods which can be utilized/consumed once, and cannot be used for further productions), which ultimately increases the GDP of Pakistan. Although Exchange Rate possesses a higher value of Coefficient, the reason for its larger value is that, its unit is Dollars per Rupee (indirect quote, i.e. USD/PKR), it means if 1 Dollars is divided by 60 Rupees (or 85), its unit value will be 0.01667 (or 0.011765 ). So, it means that, even if only a $100^{\text {th }}$ portion of this Unit (ER) changes, it can affects the GDP in a larger Amounts. In other words, GDP is very sensitive to the Changes by Exchange Rates. $\mathrm{R}^{2}$ value of our model is 0.9928 , which means that, $99.28 \%$ of our model can be explained by its independent variables 


\subsubsection{Hypothesis Testing}

The Model is fitting well with our Hypothesis that:

GDP is a Function of Exchange Rates, Imports, Exports, and Reserves Money.

That is, when exchange rates of Pakistan depreciates (e.g. Rs.60 to Rs.85 now), exports increases, and also reserves money, which ultimately increases the GDP of Pakistan. Although we may find imports against the theoretical model, But for Trade Balance (which involves the changes in imports \& exports for a particular country) is significantly affected by Exchange Rate Instability, which can help in enhancing exports, and leads to the imports of those goods, which are productive in nature (capital goods), which ultimately helps in increasing the GDP of Pakistan.

\subsubsection{Forecasting or Prediction by the Model}

The model is a good predictor of GDP values; by providing values of independent variables, we can Estimate or Predict the GDP value as follows:

Suppose by substituting the values of Exchange Rates $(0.1010101)$, Imports $(5,709,197)$, Exports $(2,958,200)$ and Reserves $(1,567,771)$ for the year 1980, we got, 24,712,516 thousands of Dollars. However the real GDP of 1980 's was $23,689,698$ thousand of Dollars, which is about $4.139 \%$ over-estimated by the model. Similarly by substituting values of independent variables for 2005, estimated GDP is 111,191,982 thousand of USD, While Real GDP is $109,600,000$ thousand of USD, which is slightly different from the original value.

Put graph \# 1 here

Use for Control or Policy Purposes

For future prediction of GDP, the Trade Policy makers, with the help of this model, can manipulate the controllable variables, to produce the desired level of the Target Variables.

\subsubsection{STABILITY TEST}

The Estimated Equation for Checking the Stability Test in our Research is:

\section{$G D P(-3)=\beta 0+\beta 1 E R(-3)+\beta 2 M(-3)+\beta 3 X(-3)+\beta 4 R M(-3)+\mu$}

Suppose, we run regression for our data, and got particular value(s) for our model; whether these values are same throughout the period or not, is what we call "Stability". There are two methods ways for Checking Data/Model's Stability:

1) Direct method

2) Indirect method.

By applying method of Stability Test's in our data indirect, we estimate the equation by breaking the data into various periods, if the values are different, in different periods, so the estimators of model are not stable. we need to explain the cause for instability in the model. If the values of the coefficients are not constant/stable throughout the periodical break-ups, then the model is said to be instable. However, there is a direct method also called "CHOW TEST" or stability test which can be run directly in e-views as "CHOW BREAK POINT TEST". It is run by giving break at a period when there should be at least 25 to 30 observations per Period break up; otherwise the results may be unreliable. The larger the number of observations (sample) available, the closer it will be to the population, and better the prediction would be.

\section{Rule of thumb for this test is}

If the value of probability (by this test) $\leq 5 \%$, or F-stat $\geq 2$, then the model is said to be stable. If the results are unfavorable i.e. $\mathrm{P} \geq 5 \%$, so we need to break up and estimate the data for periods break-ups.

\subsubsection{Results}

As shown in Appendix \#3, since probability is greater than 5\% (here it is $82.51 \%$ ), therefore we conclude that: "our model is not Stable". Probability, at lag 3 is again greater than 5\% (here it is $29.72 \%$ ), "our model is still instable", so we need to recourse to break the data into two parts as 1952-1982 and 1983-2010 period.

1952-1981:

1982-2010:

$$
\operatorname{CDF}(-3)=-477379.5+7709432 \operatorname{ER}(-3)+2.815765 M(-3)+6.109211 X(-3)-3.930060 R M(-3)+\mu
$$

$$
G D P(-3)=-12506318-77870875 E R(-3)+1.319603 M(-3)+3.391719 x(-3)+1.133344 R M(-3)+\mu
$$

We had 59 observations (closer to 60 observations - recommended minimum limit for this method). As we have found from the CHOW-Test Value that the Data is instable. This instability of the estimates is caused the 1982 Variable Exchange Policy of Pakistan, according to which the exchange rates are not fixed throughout the coming years, i.e. not stable for longer periods of time, as it was during 1950s and 1970s where one exchange rate i.e. Rs. 4.4/Us \$ and Rs 9.9/US\$ were remained fixed for a large numbers of years (about 8 years in 1950s) and (9 years in 1970s).

\subsubsection{GRANGER CAUSALITY TEST}

Statistical relationship (correlation) does not establish casual relationship. However granger proposed a test for casual relationship. In views, casual relationship can be determined between the two variables (one dependent and one independent variable) at a time. There is a causal relationship, if both depending on each other. When an independent variable is highly significant, there is higher possibility that there is causal relationship with the 
dependent variable. For more than 2 variables, Vector Auto Regression (VAR) is used for determining Causality. If $\mathrm{P} \xi 0.05$ then casual relationship exists. The numbers of lags which we include to run (in E-Views) is 2 because Granger causality test is best to apply @ 2 Lags, however we can took it till 5 lags.

Rule of Thumb: If Significant (i.e. 5.05 ) so reject $\mathrm{H}_{0}$ accept $\mathrm{H}_{\mathrm{A}}$

$\mathrm{H}_{0} \quad: \quad \mathrm{X}$ does not Granger cause $\mathrm{Y}$

$\mathrm{H}_{\mathrm{A}} \quad$ : $\quad \mathrm{X}$ Granger cause $\mathrm{Y}$.

If $\mathrm{X}$ (Independent) also depending on $\mathrm{Y}$ (dependent), and $\mathrm{Y}$ is also depending on $\mathrm{X}$, so Granger causality is existing. So we are also proving our results by Granger causality test. If existing between both so there is Multicollinerity and variable may be insignificant, if independent variables relationships also exiting, with dependent variable so there is casual relationship between them.

\section{Results}

As shown in Appendix\#4, Since for Independent Variable- Exchange Rates, i.e. for both ER with GDP, and GDP with ER, $\mathrm{P}>5 \%$ it means that we accept H0 i.e. ER does not Granger Cause GDP. For Imports and Reserves Money $\mathrm{P}<5 \%$ (for both each with GDP and GDP with each) so it means we accept HA i.e. Imports/Reserves Money both (each at a time) Granger Cause GDP. For Exports P $5 \%$ with GDP and GDP with Exports P $<5 \%$, so it means Exports not causing Granger to GDP, but GDP causing Granger to Exports.

\subsection{AUTOCORRELATION}

The classical linear regression model assumes that the error term in the regression model is uncorrelated, otherwise there will be autocorrelation. If Autocorrelation exists in the model, so parameters of the model is said to be insignificant and so results in hypothesis are unreliable. $\beta \mathbf{2}, \beta \mathbf{3}, \beta \mathbf{4}, \beta \mathbf{5}$ (independent Variable) would be significant and reliable when there is no relationship among their error terms.

\section{AUTO-CORRELATION DETECTION METHODS}

1. Durbin Watson (D-Test)

2. Run Test (Geray-Test)

4.4.1 Durbin Watson (D-Test)

Our hypothesis is:

$\begin{array}{lll}\mathrm{H}_{0} & : & \text { There is Auto-Correlation } \\ \mathrm{H}_{\mathrm{A}} & : & \text { there is no Auto-Correlation }\end{array}$

We checked the D-Value and compared it with the D-Test table values. We tabulated $\mathrm{L}=$ lower limit and U=Upper-limit. Positive autocorrelation refers that when one error is rising, another's error is also rising. Rule of thumbs is that if D value is in between 2 and 3, there is no autocorrelation. However for accuracy we need to check for D-Table values. Also D-value cannot be greater than 4 . If this value lies before $d_{1}$ value, then there is positive autocorrelation existing at a First lag. If $D$ value is in between $d_{u}$ and $4 d_{u}$, then no Autocorrelation exists. If $\mathrm{D}$ value is in between $\left(\mathrm{D}_{1}-\mathrm{D}_{\mathrm{u}}\right)$ or $\left(4 \mathrm{D}_{\mathrm{u}}-4 \mathrm{~d}_{1}\right)$, then no decision can be made because $\mathrm{D}$-watson test is limited to detect First order autocorrelation.

\section{Results}

The result shows that Durbin-Watson Stat value is 0.826911 without Lag, it means that there is possibility of autocorrelation in our data. However, on applying Lag-3 its value becomes 1.077283 and all the variables becomes significant. Since lies before 1.414, therefore there is a "Positive Autocorrelation". As our model is stable at Lag 3, so it is possible that second order or third order autocorrelation may exist, which cannot be detected by the D-Watson Test. For this purpose, we need to run another test called Run-Test.

\subsubsection{Run test}

The numbers of runs (in this test) indicates that how many times the residual value does change its signs, so we developed a series of residuals in e-views.
$\mathrm{N} 1=$ Numbers of positive runs
$\mathrm{N} 2=\quad$ Numbers of Negative runs

$\mathrm{N}=\quad$ Total numbers of runs $(\mathrm{N} 1+\mathrm{N} 2)$

$\mathrm{K}=\quad$ Numbers of Independent or Exploratory variables

If the null hypothesis of randomness is sustainable, following the properties of the normal distribution, we should expect that

$$
P\left[E-1.96 \sigma_{R} \leq R \leq E(R)+1.96 \boldsymbol{\sigma}_{R}\right]=\mathbf{0 . 9 5}
$$

If $\mathrm{R}$, the number of runs, lies in the preceding confidence interval; reject the null hypothesis, otherwise not.

\section{Results}

Since the value of (r) lies within the critical region, the results for our model are favorable. One defect of this Test is that it does not tells that whether the data has positive or negative autocorrelation

\subsection{AUTOCORRELATION REMOVAL METHODS}

1. GENERALIZED LEAST SQUARE METHOD (GLS)

2. WHITE NOISE METHOD 


\subsubsection{GENERALIZED LEAST SQUARE METHOD (GLS)}

First, we look for autocorrelation in the data, once we witnessed that autocorrelation does exist, now we will try to remove it. We will run error at its lag, so $1^{\text {st }}$ lag autocorrelation would be:

$$
\mu=\rho \mu(-1)
$$

Where $\rho$ (POW) is error term's lag coefficient.

If we check autocorrelation in our initial model and if we got first order error, so we will run in the above equation, whereas the equation of GLS is:

$\gamma=\propto+\rho \propto+\rho \beta \mathrm{x}+\rho \mu$

We will run estimated equation in E-views as: [u c u (-1)] then the coefficient, which came in this equation, is multiplied by each \& every variable of initial equation Note: coefficient as $\log 1$ is run if coefficient value is significant. Then run lag 2, 3 up to 6 . If, in any value, coefficient $\mathrm{P}$ becomes insignificant, the result becomes reliable by removing autocorrelation. If D-Watson value does not change even lag 6, So drop the variable, in such case, we need to take Log, or Reciprocal, or Transform the Model.

\section{Results}

By applying this method on simple equation, results of our model does not become stable, However by applying Lag variables, since all the variables became significant, so there is no need for applying this Method of Removal, However in this case, Heteroskedasticty methods like White Noise may be appropriate to apply for.

\subsection{2-WHITE NOISE METHOD}

It can be applied directly in E-views, so errors could be removed automatically by applying it. If one variable depending on another then standard error and T-value would be bigger value, and smaller values, respectively, by applying this Test, The result may become more reliable. However, In this case, there is no need to check Dvalue. Similarly, white Newey Test may also be used to remove errors Directly by E-views.

\section{Results:}

By applying this test, model takes following values:

\begin{tabular}{crrrr} 
& Coefficient & Std. Error & t-Statistic & Prob. \\
\hline \hline C & 6183072. & 1464539. & 4.221855 & 0.0001 \\
ER(-3) & -17853988 & 6252926. & -2.855301 & 0.0062 \\
M(-3) & 1.236149 & 0.329439 & 3.752289 & 0.0004 \\
X(-3) & 4.053665 & 0.456872 & 8.872645 & 0.0000 \\
RM(-3) & 0.818944 & 0.365702 & 2.239377 & 0.0295
\end{tabular}

Whereas, previous values were as follows:

\begin{tabular}{crrrr} 
& Coefficient & Std. Error & t-Statistic & Prob. \\
\hline \hline C & 6183072. & 1626364. & 3.801776 & 0.0004 \\
ER(-3) & -17853988 & 8055288. & -2.216431 & 0.0311 \\
$\mathrm{M}(-3)$ & 1.236149 & 0.236357 & 5.230001 & 0.0000 \\
$\mathrm{X}(-3)$ & 4.053665 & 0.327552 & 12.37563 & 0.0000 \\
$\mathrm{RM}(-3)$ & 0.818944 & 0.256055 & 3.198312 & 0.0024 \\
\hline
\end{tabular}

Briefly, Standard Error can considerably be reduced, on applying this Test.

\section{SUMMARY OF EMPIRICAL FINDINGS}

The purpose of our Research is that "To Determine whether Exchange Rate instability affects imports , Exports, Trade Balances, Foreign Reserves and GDP or not and if so in what direction". We have observed the relationship by using Pooled Data from 1952 to 2010.

We can see from the results that, if one unit of M (imports) increases, GDP is affected by 1.236 units, Where as, if one unit of X (Exports) increases, GDP is affected by 4.05 units. Unit increase in RM (Reserves) is causing GDP to affect by 0.819 units. Although Exchange Rate possesses a higher value of coefficient, the reason for its larger value is the use of indirect quotation. So, it means that, even if only a $100^{\text {th }}$ portion of this Unit (ER) changes, it can affects the GDP with a larger amount. In other words, GDP is very sensitive to the Changes by Exchange Rates. The Model is fitting well with our Hypothesis that:

GDP is a Function of Exchange Rates, Imports, Exports, and Reserves Money

That is, when Exchange Rates of Pakistan depreciates, Exports increases, and Reserves Money as well, ultimately increasing the GDP of Pakistan. Here, imports referring inputs for export like fuel and capital goods, which, irrespective of rupee depreciation, is increasing. The model can be a good predictor of GDP values. For 
the year 1980, we got estimated GDP 24,712,516 thousands of Dollars, however the real GDP of 1980 was $23,689,698$ thousand of Dollars, a minor overestimation of $4.139 \%$ by the Model.

Autocorrelation has been reduced considerably at Lag 3. Since, probability, at lag 3 is greater than $5 \%$ i.e. here it is $29.72 \%$, therefore we conclude that: "our model is not Stable", So we divided our data into 2 periods 1952 1981 \& 1982-2010 as per "Chow's Break Point Test" which again shows instability in our model. The main reason of this instability is the 1982 devaluation policy of Pakistan. According to which the exchange rates were made floating. It were during 1950 s and 1970 s where one exchange rate i.e. Rs. 4.4/Us $\$$ and Rs 9.9/US\$ were remained fixed for a long period of time (about 8 years in 1950s) and (9 years in 1970s).

Granger Causality Test is also not showing strong support for favorable results, which again indicating possibility of autocorrelation. Durbin-Watson Stat value is 0.826911 without Lag, however on applying Lag-3 its value becomes 1.077283, and all the variables becomes significant. D-watson value is less than 1.414, it means a "Positive Autocorrelation" may exists in our data without lag. We further applied the "Run Test" in order to detect, that whether data has autocorrelation or not and is it removable or not. Since the value of (r) lies with in the Critical Region, the Results for our Model are favorable. In order to remove autocorrelation, Heteroskedasticty methods like White Noise may be appropriate to apply.

\section{CONCLUSION}

Exchange rate volatility, trade and economic growth are the important components for Trade policy. The depreciation of Exchange Rate has Positive impact on the Exports, i.e. it results in increasing the Exports of Pakistan, as a result helps in maintaining a Trade Balance. Foreign Reserves of Pakistan (including Gold Reserves) has also been increased considerably with the passage of time. This is what we have propound in our hypothesis. This study will helps Trade policy makers in understanding exchange rate effects on country's trade as well for understanding its effect on economic growth of a country. Some studies from Pakistan, such as Mustafa \& Nishat (2006), Doganlar, Kemal (2006), Javeed \& Farooq (2008) have found reverse impact of depreciation of exchange rates on the economic growth. They have also found that exchange rate instability affects the exports positively and the imports negatively, consequently of exchange rates volatility improves trade balance, in the long-run.

We have used GDP as proxy for economic growth, which is the dependent variable in our model. There are four independent variables named as Exchange Rates, Imports, Exports, \& Reserves Money (including Gold Reserves). Estimated Values of our Equation exhibits that the increase in export, import, and foreign reserves due to the change (specially) depreciation of exchange rate affects the GDP of Pakistan positively. The results which we obtained from our model are significant at lag 3, and are suitable to predict, the amounts of GDP. Although, Imports sign is positive, this is against the theoretical model. This is an indication that, Pakistan is a country, whose imports are largely based on the Capital Goods (such as Machinery, Plants, \& Raw Materials etc., which can be used to produce further goods, and ultimately, increases the GDP), which ultimately increases the GDP of Pakistan.

\section{REFERENCES}

Aziz, N. (2008), "The role of Exchange rate in Trade Balance : Emperics from the Bangladesh", Phd Thesis, University of Birmingham UK

Alexdander, V. and Mandler, M. (2006), "Economic Integration, Uncertainty, and Trade - The European Experience" University of Giessen/Germany -Bloomington, April 2006

Economical Surveys of Pakistan, (2000-2011), Ministry of Pakistan, Various Issues

Hussain, A. and Muhammad, SD (2010), "The Role of Exchange Rate on Balance of Trade: Empirical from Pakistan", European Journal of Social Sciences, Vol. 14, No. 1, p. 150

Hussain A, et al (2009), "Short run and Long run Dynamics of Macroeconomics Variables and Stock prices: Case Study of KSE (Karachi Stock Exchange)" Kashmir Economic Review, Vol. XVIII, Nos. 1 \& 2,January-December, 2009, pp. $43-6$

Kemal, M. A. (2006), "Exchange Rate Instability and Trade: The Case of Pakistan" Research Report No. 186, "Pakistan Institute of Development Economics, Islamabad,

Khan, A. M., Sajid, Z. M. (2005), "The Exchange Rate and Monetary Dynamics in Pakistan: An Autoregressive Distributed lag (ARDL) Approach" The Lahore Journal of Economics, Vol. 10, p.p. 87-89

Mahmood, I. and Ali, SZ (2011), "Impact of Exchange Rate Volatility on Macroeconomic Performance of Pakistan" International Research Journal of Finance and Economics, ISSN 1450-2887, Issue 64

Muhammad et al, (2012), "Financial market integration in Pakistan", African Journal of Business Management", Vol. 6(2), pp. 608-614,18

Muhammad, S, (2011), “The Dynamic Linkages of Pakistani and Global Stock Markets: Evidence from Karachi Stock Exchange", Pakistan Journal of Commerce and Social Science Vol. 5 (2), 233-242

Mustafa, K., Nishat, M. (2006), "Volatility of Exchange Rate and Export Growth in Pakistan: The Structure and 
Interdependence in Regional Market". Institute of Business Administration, Karachi.

Qayyum, A, Kemal, A. R., (2006), "Volatility Spillover between the Stock Market and the Foreign Market in Pakistan". Working Paper\# 7, Pakistan Institute of development Economics, Islamabad.

Siddiqui, R., and A. Salam (2000), "Exchange Rate Variability and Trade between Pakistan and Japan". Presented at the Conference organized by QAU and Japan Foundation, October 24-25, 2000, Islamabad, Pakistan.

Shaista Alam (2010), “A Reassessment of the Effect of Exchange Rate Volatility on Pakistan's Exports Demand: ARDL Approach", European Journal of Economics, Finance and Administrative Sciences ISSN 14502275 Issue 21

Zakaria, M. and Ghauri, AB (2011), “Trade openness and real exchange rate: Some Evidence from Pakistan”, Romanian Economic Journal, March 2011, Vol. XIV No. 39, pp 201-229

Zulfiqar Hyder and Adil Mahboob (2006) "Equilibrium real effective exchange rate and exchange rateMisalignment in Pakistan", SBP Report

Zahoor, H., Javeed and Farooq, M. (2008), "Economic Growth and Exchange Rate Volatility in Case of Pakistan", Pakistan Journal of Life and Social Science, Vol. 7(2), pp. 112-118 
The IISTE is a pioneer in the Open-Access hosting service and academic event management. The aim of the firm is Accelerating Global Knowledge Sharing.

More information about the firm can be found on the homepage:

http://www.iiste.org

\section{CALL FOR JOURNAL PAPERS}

There are more than 30 peer-reviewed academic journals hosted under the hosting platform.

Prospective authors of journals can find the submission instruction on the following page: http://www.iiste.org/journals/ All the journals articles are available online to the readers all over the world without financial, legal, or technical barriers other than those inseparable from gaining access to the internet itself. Paper version of the journals is also available upon request of readers and authors.

\section{MORE RESOURCES}

Book publication information: http://www.iiste.org/book/

\section{IISTE Knowledge Sharing Partners}

EBSCO, Index Copernicus, Ulrich's Periodicals Directory, JournalTOCS, PKP Open Archives Harvester, Bielefeld Academic Search Engine, Elektronische Zeitschriftenbibliothek EZB, Open J-Gate, OCLC WorldCat, Universe Digtial Library, NewJour, Google Scholar

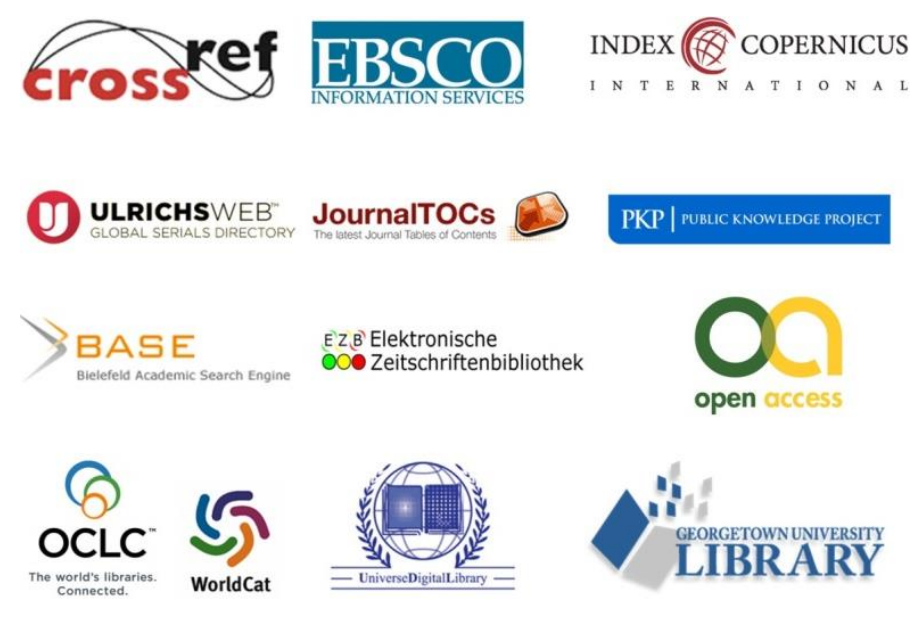

